\title{
PEMBERDAYAAN MASYARAKAT MANTAN BURUH MIGRAN KORBAN TRAFFICKING DI KABUPATEN WONOSOBO
}

\author{
Tissa Silvia $^{1}$ dan Sugi Rahayu ${ }^{2}$
}

\begin{abstract}
This research This research aimed to analyze the community empowerment of exmigrant labors in Kampung Buruh Migran (KBM) of Tracap Village, Kaliworo subdistrict, Wonosobo regency. This research result in the implementation of ex migrant empowerment was implemented by strengthening the economic capacity and human capacity. In the implementation of ex migrant empowerment there was decreased of level participation from ex migrant labors, from 297 members: recorded 72 members following empowerment in 2012 and now it was decreasing to 29 active mambers. Succesfull empowerment activity in strengthening economic capacity were koperasi and saving and loan. Meanwhile unseccesfull empowerment activities were farming and agriculture activities. The strengthening capacity and socialization were not yet effective. The empowerment were conducted in seven steps of empowering. The resistans factors were low quality of human resources, lack of coordination with government, the support expectation of targeted community to obtain goods and money, and lack of governments interventation toward the sustainability of the program.
\end{abstract}

Keyword: Empowerment, Ex Migrant Labor, and Kampung Buruh Migran

\begin{abstract}
ABSTRAK
Penelitian ini bertujuan untuk mengetahui pelaksanaan pemberdayaan masyarakat mantan buruh migran di Kampung Buruh Migran Desa Tracap Kecamatan Kaliwiro Wonosobo. Desain penelitian yang digunakan adalah deskriptif kualitatif. Hasil penelitian menunjukkan pemberdayaan masyarakat mantan buruh migran korban trafficking di Kampung Buruh Migran dilaksanakan melalui penguatan ekonomi dan penguatan kapasitas. Dalam pelaksanaan pemberdayaan terjadi penurunan tingkat partisipasi mantan buruh migran dari 297 orang, tercatat 72 orang mengikuti pemberdayaan pada tahun 2012 dan sekarang menurun menjadi 29 anggota aktif. Kegiatan pemberda yaan yang berhasil dalam penguatan ekonomi dibidang koperasi dan simpan pinjam sedangkan pemberdayaan yang belum berhasil dibidang peternakan dan pertanian, kemudian dalam penguatan kapasitas pelatihan dan sosialisasi belum berjalan efektif. Keseluruhan pemberdayaan dilaksanakan melalui tujuh tahapan pemberdayaan. Faktor penghambat yang mempengaruhi tercapainya tujuan pemberdayaan adalah kualitas SDM mantan buruh migran yang masih rendah, kurangn ya koordinasi dengan pemerintah, harapan masyarakat sasaran mendapatkan bantuan dalam bentuk barang atau uang dan kurangnya peran serta pemerintah dalam keberlanjutan program.
\end{abstract}

Kata Kunci: Pemberdayaan, Mantan Buruh Migran, dan Kampung Buruh Migran

1,2 Jurusan Ilmu Administrasi Negara, Fakultas Ilmu Sosial, Universitas Negeri Yogyakarta 


\section{PENDAHULUAN}

Permasalahan ekonomi merupakan masalah utama yang dihadapi suatu negara dan dampaknya dirasakan oleh masyarakat. Salah satu penyebab gagaln ya pembangunan di Indonesia adalah adanya permasalahan pengangguran. Ketidakmampuan pemerintah dalam memberikan peluang kerja kepada masyarakat, mendorong mas yarakat Indonesia untuk melakukan migrasi keluar negeri menjadi Tenaga Kerja Indonesia (TKI).

Kabupaten Wonosobo adalah pengirim TKI terbesar kedua di Jawa Tengah dinyatakan oleh BNP2TKI. TKI ilegal memiliki risiko mendapatkan tindak kekerasan, pembayaran gaji tidak sesuai kontrak, kriminalitas sampai dengan praktik trafficking atau tindak pidana perdagangan orang. Dalam melindungi para tenaga kerja dari praktik trafficking pemerintah telah memiliki peraturan perundangan yaitu Undang-Undang Republik Indonesia Nomor 21 Tahun 2007 tentang Pemberantasan Tindak Pidana Perdagangan Orang.

Desa Tracap Kecamatan Kaliwiro merupakan desa yang ma yoritas penduduk perempuannya bekerja sebagai TKI dan hampir 90 persen dari TKI atau buruh migran yang ada merupakan korban tindakan trafficking (Serikat Buruh Migran Indonesia Kab Wonosobo 2016).

Permasalahan trafficking tersebut merupakan salah satu contoh dampak dari pemerintah yang belum dapat memberikan lapangan pekerjaan bagi masyarakat untuk mencapai taraf kehidupan yang la yak. Dalam hal ini tugas pemerintah tidak hanya melakukan penempatan dan perlindungan terhadap para TKI namun juga melakukan pemberdayaan kepada para purna TKI. Lembaga swadaya masyarakat yaitu Serikat Buruh Migran Indonesia (SBMI) Kabupaten Wonosobo membentuk kampung buruh migran di Desa Tracap sebagai upaya dalam pemberdayaan mas yarakat mantan buruh migran agar dapat mencapai kesejahteraan.

Upaya pemberda yaan masyarakat mantan buruh migran di Desa Tracap Kecamatan Kaliwiro Kabupaten Wonosobo dilakukan melalui penguatan ekonomi yaitu koperasi buruh migran, kelompok simpan pinjam, peternakan ayam dan kambing, dan budidaya jamur tiram. 
Dilain pihak adanya pemberdayaan yang diprakarsai oleh SBMI DPC Kabupaten Wonosobo belum dapat mengurangi jumlah mantan buruh migran yang kembali bekerja keluar negeri. Pasalnya diadakan kampung buruh migran tersebut adalah untuk mengurangi jumlah warga Desa Tracap yang bekerja keluar negeri namun senyatan ya masih terdapat mantan buruh migran yang kembali bekerja diluar negeri. Pemikiran terkait mendapat penghasilan yang lebih banyak jika bekerja di luar negeri membuat mantan buruh migran bekerja kembali keluar negeri.

Kondisi ekonomi dan kesejahteraan para mantan buruh migran di Desa Tracap tergolong masih rendah meskipun sudah diadakan beberapa kegiatan berupaya untuk memberdayakan mantan buruh migran agar lebih mandiri namun pada hasilnya hal tersebut belum dapat meningkatkan perekonomian para mantan buruh migran. Beberapa pelatihan yang bertujuan memberikan simultan kepada mantan buruh migran untuk melakukan usaha justru mengalami kendala, seperti usaha ternak kambing yang justru mengalami kegagalan hal ini memberikan kerugian dan terpaksa usaha ternak kambing harus diberhentikan terlebih dahulu. Kurangnya peran serta pemerintah juga menjadi kendala dalam pelaksanaan program pemberdayaan yang ada, kontribusi yang diberikan oleh pemerintah lebih bersifat reaktif.

$$
\text { Dengan demikian Pemerintah }
$$

Kabupaten Wonosobo dirasa perlu untuk memberikan dukungan dalam pelaksanaan pemberdayaan masyarakat mantan buruh migran di Desa Tracap Kecamatan Kaliwiro Kabupaten Wonosobo sehingga dapat meningkatkan kesejahteraan para mantan buruh migran. Berdasarkan paparan tersebut, maka peneliti ingin mengkaji lebih dalam terkait dengan Pemberdayaan Mas yarakat Mantan Buruh Migran Korban Trafficking di Kampung Buruh Migran Desa Tracap Kecamatan Kaliwiro Kabupaten Wonosobo.

\section{METODE}

Desain penelitian yang digunakan dalam penelitian ini adalah penelitian dengan metode deskriptif kualitatif. Penelitian kualitatif adalah penelitian dengan filsafat postpovitisme digunakan pada kondisi objek yang alamiah dan peneliti sebagai informan kunci. Dalam penelitian ini, instrument penelitian yaitu peneliti sendiri dibantu pedoman wawancara, observasi dan dokumentasi. 
Penelitian ini menggunakan teknik analisis data menurut Miles dan Huberman1984 dalam (Sugi yono, 2015:246). Teknik analisis ini mempunyai empat alur yangdigunakan yaitu pengumpulan data, reduksi data, penyajian data dan kesimpulan atau verifikasi.

\section{HASIL DAN PEMBAHASAN}

Pemberdayaan menurut Prijono dan Pranarka (1996:77) memiliki dua makna dimana pengertian pemberdayaan yang pertama adalah to give power authority dimana hal ini dimaknai meliputi memberikan kekuasaan, memindahkan kekuatan atau mendelegasikan kewenangan kepada pihak yang kurang atau bahkan belum berdaya. Kemudian pemaknaan yang kedua adalah to give ability to enable dimana arti dari makna yang kedua ini adalah memberikan kemampuan atau keberdayaan serta memberikan peluang kepada pihak- pihak lain untuk melakukan sesuatu.

SBMI DPC Kab.Wonosobo merupakan pihak yang mendampingi pemberdayaan di Kampung Buruh Migran hal ini didasarkan agar pemberdayaan yang dilakukan kepada mantan TKI korban trafficking dapat merubah keadaan ekonomi maupun sosial mereka sehingga dapat lebih berdaya. Pemberdayaan dilaksanakan melalui dua jenis pemberdayaan yaitu pemberdayaan melalui penguatan ekonomi dan penguatan kapasitas. Kedua pemberdayaan tersebut melalui tahapantahapan pemberdayaan berdasarkan teori (Isbandi 2008:244-258).

\section{Pemberdayaan melalui penguatan ekonomi}

Pemberdayaan melalui penguatan ekonomi dilaksanakan dengan kegiatan usaha peternakan kambing, peternakan ayam, budidaya jamur tiram, koperasi dan simpan pinjam. Pemberdayaan ekonomi diharapkan dapat memperbaiki kondisi perekonomian mantan buruh migran agar lebih sejahtera.

1. Tahap Persiapan

Tahap Persiapan dilaksanakan dari segi persiapan petugas dan persiapan lapangan (Isbandi 2008:244). Dimulai dengan pengelompokan, pengorganisasian dan pendataan mantan buruh migran Dilanjutkan sosialisasi terkait program pemberdayaan dan penekanan partisipasi mantan buruh migran. 
2. Tahap assessment

Tahap assessment dilakukan dengan identifikasi masalah ataupun kebutuhan dan juga sumber da ya yang dimiliki oleh

kelompok sasaran.

(Isbandi 2008:244-258). Pengkajian dilakukan oleh SBMI DPC Kab. Wonosobo dengan berembug atau bermusyawarah dengan mantan buruh migran yang ada di Desa Tracap dan mengundang tokoh masyarakat. Dari hasil pengidentifikasian masalah didapatkan hasil bahwa permasalahan mantan buruh migran yakni belum adanya pemasukan setelah kembali ke Indonesia. Sedangkan potensi yang dimiliki adalah kemauan para mantan buruh migran untuk bergerak dan bekerja secara gotong royong.

\section{Tahap Perencanaan}

Dalam tahapan ini para pelaku perubahan tersebut berupaya untuk menggerakkan warga untuk dapat lebih partisipatif (Isbandi 2008:244-258). Mantan buruh migran berpartisipasi dan menentukan program pemberdayaan dari permasalahan yang dihadapi. Kebutuhan akan penghasilan bulanan yang nantinya dapat memperbaiki perekonomian para mantan buruh migran diwujudkan dalam bentuk pemberdayaan melalui penguatan ekonomi dengan usaha ternak kambing, ternak ayam, kelompok simpan pinjam dan koperasi. Dalam perencanaan ini para mantan buruh migran bersama SBMI DPC Kab. Wonosobo menyusun persiapan untuk pencarian dana, dan narasumber pelatihan.

\section{Tahap Perumusan Rencana Aksi}

Dalam tahapan ini para pelaku perubahan akan membantu kelompok sasaran untuk menentukan program dan kegiatan apa yang akan mereka lakukan guna mengatasi permasalahan yang dihadapi (Isbandi, 2008:250). Dilaksanakan musyawarah setelah bantuan dana disetujui oleh (IOM) untuk pembelian 100 ekor kambing Ciamis dan 500 ekor ayam petelur. Model pengelolaan shift menjadi pilihan. Kelompok simpan pinjam ditentukan untuk memberikan setoran $\mathrm{Rp} 5$ ribu rupiah setiap pertemuan, selain itu juga ditetapkan adan ya suku bunga dalam peminjaman yaitu sebesar 2,5\% dan dilakukan pertemuan setiap tgl 18 . Koperasi telah mendapatkan persetujuan bantuan dana dari BNP2TKI dan Desa Tracap, ditentukan Dusun Jojogan sebagai lokasi pendirian koperasi.

5. Tahap Pelaksanaan

Dalam tahapan ini tahap terpenting dalam proses pemberdayaan 
ada pada tahap pelaksanaan ini dimana sesuatu yang telah direncanakan akan terlihat berhasil tidaknya dalam tahap pelaksanaan (Isbandi, 2008:251). Usaha peternakan kambing dan a yam mengalami kegagalan karena metode pengelolaan shift, dan rendahnya SDM para pengelola. Kemudian diganti dengan budi da ya jamur tiram yang juga hanya berjalan satu tahun dan mengalami kegagalan, sehingga sekarang kembali melakukan usaha ternak kambing namun dengan metode pengelolaan yang berbeda.

Diberikan pelatihan ternak kambing oleh Dinas Peternakan dan pemberian pelatihan ternak ayam oleh BP3TKI. Simpan pinjam berjalan sesuai dengan perencanaan dan terdapat 22 anggota aktif, sistem pembukuan masih menggunakan pembukuan manual. Usaha koperasi berjalan cukup baik dan sekarang memiliki satu cabang di Desa Tracap.

\section{Tahap evaluasi}

Tahapan ini merupakan alat pengawasan dari warga dan petugas terhadap program yang sedang berlangsung pada pemberdayaan masyarakat lebih baik dilakukan dengan melibatkan warga (Isbandi 2008: 252253). Usaha peternakan dilaksanakan evaluasi satu bulan sekali dengan berkumpulnya kelompok simpan pinjam yaitu tgl 18. Pemerintah Desa ikut dalam proses evaluasi. Dinas Peternakan melakukan evaluasi dari kegiatan pengobatan hewan massal. Simpan pinjam dilaksanakan evaluasi satu tahun sekali bersamaan dengan pembagian hasil usaha yaitu mendekati Hari Raya Idul Fitri. Koperasi dilaksanakan evaluasi satu tahun sekali bersamaan dengan simpan pinjam dan menghadirkan perangkat desa sebagai bentuk pertanggung jawaban pemberian dana.

\section{Tahap terminasi}

Tahap terminasi atau tahap akhir pemberdayaan dimana sudah selesainya hubungan secara formal dengan komunitas sasaran (Isbandi, 2008:257). Dalam tahapan ini SBMI DPC Kab. Wonosobo belum memberikan jangka waktu pemberhentian pendampingan pemberdayaan yang dilakukan di Kampung Buruh Migran.

\section{Pemberdayaan melalui Penguatan}

\section{Kapasitas}

1. Tahap Persiapan

Tahap persiapan dilakukan dari segi persiapan petugas dan persiapan lapangan (Isbandi, 2008:244). Pemberdayaan penguatan kapasitas ini 
dilakukan dari persiapan para petugas dari BKBPPA, petugas mempersiapkan untuk memberikan pelatihan sebagai media transfer ketrampilan yang nantinya dibutuhkan sesuai dengan kondisi mantan buruh migran. Disnakertrans juga melakukan persiapan petugas dengan menyamakan persepsi para pelaku pemberdayaan.

2. Tahap assesment

Tahap pengkajian dilakukan dengan identifikasi masalah ataupun kebutuhan dan juga sumber da ya yang dimiliki oleh kelompok sasaran. (Isbandi 2008:244-258). Hasil pengidentifikasian masalah yang dihadapi mantan buruh migran adalah belum adanya pemasukan setelah kembali ke Indonesia karena minimnya ketrampilan yang dimiliki dan keharmonisan keluarga mantan buruh migran yang juga dirasa kurang. Sedangkan potensi yang dimiliki adalah kemauan para mantan buruh migran untuk bergerak dan bekerja secara gotong royong. SBMI DPC Kab. Wonosobo ikut serta mendampingi pengkajian yang dilaksanakan oleh SKPD terkait.

3. Tahap Perencanaan

Tahapan ini adalah tahapan dimana para pelaku perubahan tersebut berupaya untuk menggerakkan warga untuk dapat lebih partisipatif (Isbandi

2008:244-258).

Belum dimilikinya ketrampilan-ketrampilan para buruh migran mendorong untuk merencanakan dilaksanakannya pelatihan yang dapat menambah ketrampilan sehingga dapat bermanfaat.

4. Tahap Perumusan Rencana Aksi

Dalam tahapan ini para pelaku perubahan akan membantu kelompok sasaran untuk menentukan program dan kegiatan apa yang akan mereka lakukan guna mengatasi permasalahan yang dihadapi (Isbandi 2008:250). Pelatihan tata boga dipilih karena memberikan ketrampilan untuk membuat usaha katering dan waktu pelaksanaan yang berdekatan dengan Hari Raya Idul Fitri.

Kemudian pelatihan membuat dompet didasari karena pelatihan membuat ketrampilan barang yang nantinya dapat dijual dan menambah pendapatan mantan buruh migran. Sosialisasi keharmonisan keluarga dipilih berdasarkan identifikasi BKBPPA. Sosialisasi migrasi yang aman dipilih karena kecenderungan TKI merupakan korban TPPO. 
5. Tahap Pelaksanaan

Tahap terpenting dalam proses pemberdayaan ada pada tahap pelaksanaan ini dimana sesuatu yang telah direncanakan akan terlihat berhasil tidaknya dalam tahap pelaksanaan (Isbandi 2008:251). Pelatihan tata boga diikuti oleh para mantan buruh migran namun hanya tercatat 2 mantan buruh migran yang mengimplementasikan ilmu tersebut untuk usaha katering. Kemudian pelatihan membuat dompet berjalan sesuai perencanaan dengan mendatangkan pengusaha dompet tersebut untuk menjadi narasumber namun belum ada mantan buruh migran yang tercatat mengimplementasikan ilmu tersebut. Sosialisasi keharmonisan keluarga diberikan oleh BKBPPA dilaksanakan sesuai perencanaan. Sosialisasi migrasi yang aman dilaksanakan oleh Disnakertrans mendatangkan tidak hanya buruh migran melainkan keluarga sehingga dapat mengedukasi tidak hanya mantan TKI.

6. Tahap evaluasi

Tahap evaluasi adalah alat pengawasan dari warga dan petugas terhadap program yang sedang berlangsung pada pemberdayaan masyarakat lebih baik dilakukan dengan melibatkan warga (Isbandi, 2008: 252253). Bentuk evaluasi dari pemerintah penyelenggara pelatihan adalah evaluasi selama satu tahun sekali yang dilakukan oleh BKBPPA. Evaluasi dilaksanakan tidak terkhusus untuk mengkaji pelatihan di Kampung Buruh Migran saja melainkan keseluruhan pelatihan yang dilaksanakan oleh BKBPPA di Kabupaten Wonosobo. Sedangkan evaluasi dari hasil sosialisasi yang dilaksanakan oleh Disnakertrans lebih kepada pemantauan terkait TKI yang berangkat keluar negeri melalui jalur legal, apakah terdapat kenaikan atau penurunan.

7. Tahap terminasi

Tahap terminasi merupakan akhir pemberdayaan dimana sudah selesainya hubungan secara formal dengan komunitas sasaran (Isbandi, 2008:257). Dalam tahapan ini pemutusan hubungan secara resmi oleh SBMI DPC Kab.Wonosobo juga belum dapat dilaksanakan sebagai lembaga penanggungjawab Kampung Buruh Migran Indonesia.

Dalam pelaksanaan pemberdayaan masyarakat mantan buruh migran terdapat faktor-faktor penghambat antara lain: kualitas SDM yang masih rendah, kurangnya koordinasi dengan 
Pemerintah, harapan masyarakat sasaran mendapatkan bantuan dalam bentuk barang atau uang, minimnya campur tangan pemerintah dalam keberlanjutan program.

\section{SIMPULAN}

Berdasarkan pembahasan maka peneliti menyimpulkan sebagai berikut: Pemberdayaan masyarakat mantan buruh migran korban trafficking di Kampung Buruh menunjukan penguatan ekonomi terdapat kegagalan yaitu usaha ternak kambing, usaha ternak a yam dan budi daya jamur tiram sedangkan pemberdayaan yang dianggap berhasil yaitu dari kelompok simpan pinjam dan koperasi. Pelatihan yang dilaksanakan sebagai penguatan kapasitas belum dapat diimplementasikan secara maksimal. Pemberdayaan yang dilaksanakan belum berjalan efektif dilihat dari jumlah partisipasi mantan buruh migran yang mengalami penurunan uang, minimnya campur tangan pemerintah dalam keberlanjutan program.

\section{DAFTAR PUSTAKA}

Haris, Abdul. 2005. Gelombang Migrasi dan Jaringan Perdagangan Manusia. Yogyakarta: Pustaka Pelajar
Ahmadi, Abu. 2003. Ilmu Sosial Dasar. Jakarta: PT. Asdi Mahasatya Andi Prastowo.2012. Metode Penelitian Kualitatif dalam Perspektif Rancangan Penelitian. Jakarta: Ar-Ruzz Media.

Anwar. 2007. Manajemen Pemberdayaan Perempuan (Perubahan Sosial Melalui PembelajaranVocational Skills Pada Keluarga Nelayan). Bandung: Alfabeta.

Sulistyani, Ambar Teguh. 2007. Kemitraan dan Model-model Pemberdayaan. Yogyakarta: Gava Media.

Bungin, Burhan. 2010. Penelitian Kualitatif: Komunikasi, Ekonomi, Kebijakan Publik dan Ilmu Sosial lainya. Jakarta: Kencana Prenama Media Group

Maryati, Depi. 2016. Pemberdayaan Mayarakata Dalam Program Pascatambang Pasir Besi Oleh PT Aneka Tambang TBK Di Kecamatan Grabag, Kabupaten Purworejo. Skripsi. Yogyakarta: Universitas Negeri Yogyakarta

Herdiansyah, Haris. 2010. Metode Penelitian Kualitatif untuk Ilmuilmu Sosial. Jakarta: Selemba Humanika

Herdiansyah, Haris.2015. Wawancara, Observasi dan Focus Groups. Jakarta: Raja Grafindo Persada

Mantra, Ida Bagoes. 2003. Demografi Umum. Yogyakarta: Pustaka Pelajar

Adi, Isbandi Rukminto. 2008. Intervensi Komunitas Pengembangan Masyarakat Sebagai Upaya 
Pemberdayaan Masyarakat. Jakarta: Rajawali Press

Hasanah, Jumrotul. 2015. Pemberdayaan Masyarakat Berketerbelakangan Mental dalam

Mencapai Masyarakat di Kampung Idiot Kecamatan Jambon Kabupaten Ponorogo. Yogyakarta: Skripsi. Universitas Negeri Yogyakarta.

Khoerudin, H. 1992. Pembangunan Masyarakat. Yogyakarta: Liberti.

Lee, Everett S. 2000. Teori Migrasi. Translated by Hans Daeng. Ditinjau kembali oleh Ida Bagus Mantra. Edisi VII. Yogyakarta: UGM Press.

M. Djunaidi Ghony dan Fauzan Almanshur. 2012. Metodologi Penelitian Kualitatif. Jogjakarta: Ar-Ruzz Media.

Moleoung, J Lexy. 2014. Metode Penelitian Kualitatif Edisi Revisi. Bandung: PT Remaja Rosdakarya

Kuncoro, Mudrajad. 2004. Ekonomi Pembangunan, Teori Masalah dan Kebijakan. Yogyakarta: UPP AMP YKPN

Mulyadi S. 2003. Ekonomi Sumber Daya Manusia. Jakarta : Raja Grafindo Persada

Onny S. dan AMW. Pranarka. 1996. Pemberdayaan: konsep, kebijakan, dan Implementasi. Jakarta: CSSIS

$\begin{array}{crrr}\text { Peraturan Menteri } & \text { Dalam } & \text { Negeri } \\ \text { Nomor 26 } & \text { Tahun } & 2012 \\ \text { Tentang } & & \text { Pemberdayaan } \\ \text { Masyarakat } & & \text { yang } & \text { akan }\end{array}$

menjadi calon dan purna Tenaga Kerja Indonesia

Rahardjo $\quad 2006$. Membangun Desa Perspektif. Yogyakarta: Graha Ilmu

Sanapiah Faisal. 2007. Format-format Penelitian Sosial. Jakarta: Raja Grafindo Persada.

Kertonegoro, Sentanoe. 1994. Migrasi Tenaga Kerja. Jakarta: Agung.

Sri Kuntari. 2009. Strategi Pemberdayaan (Quality Growth) Melawan Keminskinan. Yogyakarta: B2P3KS Press.

Sugiyono. 2015. Metode Penelitian Kuantitatif Kualitatif dan $R \& D$. Bandung: Alfabeta

Suhartini dkk. 2005. Model-model Pemberdayaan Masyarakat. Yogyakarta: Pustaka Perantren Lkis

Suharto, E. 2005. Membangun Masyarakat Memberdayakan Rakyat, Bandung: PT Refika Aditama

Totok M dan Poerwoko S. 2013. Pemberdayaan Masyarakat (Dalam Perspektif Kebijakan Publik). Bandung: Alfabeta

Undang-undang Nomor 21 Tahun 2007 tentang Pemberantasan Tindak PidanaPerdagangan Orang

Vandy Yoga Swara. 2012. Perubahan Habitus TKI Korban Perdagangan Manusia Melalui Pemberdayaan di Kampung Buruh Migran Desa Tracap Kabupaten Wonosobo. Skripsi. Yogyakarta: Universitas Gadjah Mada 